\title{
Prioritized Content of Islamic Television Channels: An Analytical Study of Alhijrah TV
}

\author{
OSAMA KANAKER \\ Universiti Sains Islam Malaysia
}

\begin{abstract}
In the world of media and communication, the producers of content are major contributors who create issues for an audience to think about. This content is not randomly created, but rather created based on certain agendas. This paper analyzes the content of the Alhijrah channel, a Malaysian Islamic TV. The objective of this study is to discover the prioritized Islamic content broadcast by Alhijrah TV that contributes to shaping the perception of Islam among viewers. To achieve this objective, content analysis, observation and interviews were conducted. The sample of the study was the last broadcasting season of 2020. It was found out that Alhijrah divided its programs into eight genres. The leading genre was a magazine that accounted for $46.56 \%$ of the sample, and the leading programs were the programs of the noble Qur'an. Alhijrah resorted to shopping programs that accounted for almost $17 \%$ of the Alhijrah content. Alhijrah also broadcast seven live programs that made up $16.71 \%$ of its programs. Alhijrah also broadcast limited programs of animation, drama, concert and talk show. This study recommends Islamic television channels and producers of Islamic content to align their agendas with the noble Qur'an to prioritize what Allah SWT prioritized to guide the audience to Allah SWT implementing the methods that He set for us.
\end{abstract}

Keywords: Content, television, Islam, Alhijrah TV, agenda-setting theory.

\section{INTRODUCTION}

Despite the vast spread of social media worldwide, television still holds its position for a large portion of viewers especially the audience who is unable to get access to the new technologies either for lack of interest, age or poverty. Serious content such as news and religious knowledge is still sought mainly from television. The general norm of television is to be variety channels, but recently television channels move toward especially. Some of the specializations is news, sport, documentary, entertainment or religion. Since Islam is the final chosen religion of God for humanity, Muslims, as a religious duty, have to disseminate its message worldwide implementing all possible honest methods.

Television is not an exception. Therefore, television channels that are specialized in disseminating the message of Islam emerged in the Muslim world. According to Moll (2010), the first Arabic Islamic television channel was Iqraa TV that was launched on the 21st of October 1998. Then, plenty of Islamic channels in the Arab world emerged such as Almajd TV Network, Al-Manar TV, Al Resalah Satellite TV and Al-Nas TV. Some of these channels are variety and others are specialized in certain fields such as Qur'an or hadith only. Islam channel also appeared in the UK which broadcast Islamic content in English. Malaysia as a Muslim country is not an exception. It has two channels that are allocated to broadcast Islamic contents: Astro Oasis TV and TV Alhijrah. Astro Oasis identify itself as a progressive lifestyle channel for Muslims that contains Islamic based educational, entertainment and documentary-styled programs in HD quality. Alhijrah promotes itself as the first Islamic TV station in Malaysia for both Muslims and non-Muslims. 


\section{BACKGROUND}

According to Wilt (n.d.), "the birth of the electronic television age is almost impossible to pinpoint exactly. Due to the numerous contributors that helped to develop this new medium, it is even more difficult to acknowledge any one person for its invention." Being producers, western manufacturers export television stations, sets and experts to non-producer countries, among which are Muslim countries.

God, in his final message, does not address those who submitted to Him only but all human beings at large. This notion identifies with the concept of mass communication which is meant for communicating with the masses who are large in numbers. In the early period of Islam, Muslims pioneered the means of communication that was available at the time. At the time of the first Muslim caliph, Abu Bakr Assidiq, Muslims compiled the Qur'an in a single book. In a later stage, Muslims compiled the Hadith of Prophet Muhammad in books. However, Muslims in the current is are not inventive for modern media technologies.

Concerning television channels that are meant to communicate the message of Islam, there is an ongoing debate among scholars about naming them. Some researchers tend to call them Islamic television because they focus on Islam. However, others such as Mustafa Kanakir (2007), does not accept that name arguing that Islam is a comprehensive system for life and these channels are focusing on a portion of it that creates a misconception about Islam by non-Muslim and Muslim viewers. It might be perceived that Islam is limited to what is broadcast on the screen.

Al-Qudat (1994) argues that television broadcasting in Muslim countries begins in the mid-twentieth century. However, Boyd (1982) stated that all television stations in the Arab world were purchased from and installed by West European and American equipment manufacturers: usually the installation agreement called for production training of the buyers by western experts, or for their training in the country where the equipment was manufactured. Ayish (2002) goes beyond importing technology to importing content. He stated that economics and politics seem to have combined in providing a fertile ground for the flow of foreign television imports from Western Europe and North America into Arab Muslim World television, allowing exposure to new cultural products with little relevance to their Arab-Islamic traditions. This foreign program dominance was first noted in the 1970s and 1980s. In the satellite television era, it has become evident not only in the growing volume of imported television contents but also in the adoption of program formats that emanate primarily from Western visual cultural modes.

Even half a century after introducing television in Muslim countries, television programs remain affected by western programs. Today, Muslims produce television content, but Rugh (2007) states that echoes of American debate programs in Aljazeera's contentious discussion shows, and Arab reality shows, especially those that involve viewer voting such as Super Star and Star Academy, have taken format ideas from the West. According to the Arab Advisor Group Annual Report of 2009, thirty-nine religious television channels in the Arab World were broadcasting. These channels are Islamic because the prevailing religion of the region is Islam. Unfortunately, there is no authentic recent data about the number of Islamic television channels.

As mentioned in the introduction, Malaysia as a Muslim country has two television channels that are aimed at delivering the Islamic message. Astro Oasis was launched in October 2007 (Rosidayu, 2010). Alhijrah TV was launched at the end of 2010 (Buyong \& Ismail, 2012). Malay is the primary language that occupies both channels. The main purpose of establishing the Alhijrah channel is to provide a TV platform to educate, entertain and unite 
the ummah through creative and quality broadcasting that is appropriate to the local and international community. Alhijrah produces content that suites all ages for both Muslim and non-Muslim audiences. However, the main target is young people and audiences under 40 (Alhijrah TV, 2021).

Alhijrah set a mission for their broadcasting to invite the community to make continuous migration towards goodness in all areas of life. Alhijrah seeks to achieve this mission through nine principles (Alhijrah TV, 2021). First, provide content in the form of magazines, documentaries, dramas, news, current affairs, entertainment and leisure based on Islamic principles and universal values. Second, ensure that content is interesting, informative and suitable for all walks of life. Third, use the latest transmission, broadcasting and IT technologies as well as channelling content across various platforms. Fourth, implementing professional, moral, transparent, dynamic and creative management practices. Fifth, implementing policies, procedures and work processes that are efficient, effective and following the best practices. Sixth, progress human capital development to navigate the dynamic media industry. Seventh, establish a strategic alliance with various parties on the concept of a win-win situation. Eight, provide innovative and creative sponsorship and marketing packages. Finally, introduce a company performance system that shows outstanding employees.

Furthermore, Alhijrah's agenda is to offers fresh content as well as programs that meet the needs of today's viewers. Alhijrah states on their website that their content is researched and developed not only to attract the attention of the audience through creative publications but to prioritize current tastes based on Islam. All the content published are based on Islamic values and centred on four principles (Alhijrah, 2021). The first principle is honesty. It is implemented by firmly adhering to the teachings and principles of Islam and respecting the local culture and traditions that do not violate the religion as well as adhering to the height of morality and universal values. The second principle is openness. It is implemented to offer innovative knowledge and ideas and respect the diversity of views and prioritize unity and find solutions through knowledge and information especially from the noble Qur'an and hadith of Prophet Muhammad PBBHU. The third principle is the progressiveness. It is meant to encourage the comparison of ideas capable of lifting the paradigm and absorption of new technologies especially in the field of broadcasting and offering innovation in multi-platform medium and new media. Finally, relevance, which is to stay up to date with new trends locally and internationally and broadcast content that is relevant to current developments and situations using a friendly and interactive approach.

\section{ISLAMIC TELEVISION PROGRAMS}

Content of television is crucial as it provides meaningful insight and results in different understanding among viewers. Zulkiple (1998) argues that themes of programs should present Islam as a progressive religion showing how Muslims accommodate themselves to the fast-changing pace of the present world without abandoning their religious teaching. Zulkiple (2006) further argues that It is common in the present practice of broadcasting stations in the Muslim World to classify their programs into several categories, such as informative, education, cultural, entertainment and religious programs. As far as the last is concerned, an exclusive unit or section has usually been established to produce religious programs assuming that it would cater to the needs of Muslims. Islamic television should intuitively be emanated from Islamic sources. The noble Qur'an is the fundamental source of 
Islam. Therefore, the themes of the noble Qur'an are supposed to shape the Islamic content that is communicated on television because the noble Qur'an is the book that God communicated with human beings to submit to Him. Surveying the noble Qur'an, seven major themes emerged, but the noble Qur'an is not limited only to these seven.

The first theme is knowledge. It is a well-established theme in the noble Qur'an. According to Davies (1987), the Muslim ummah is directed to be a knowledge-based and information-rich community. Pasha (1993) clarifies the importance of knowledge by saying that knowledge is the key to the human condition and the power that drives human civilization. The importance of knowledge is stressed in the noble Qur'an. At the beginning of the al-Qalam (The Pen) chapter Allah (SWT) swears by instruments of knowledge i.e., the pen and inkwell. Knowledge in the noble Qur'an is not only religious-oriented, but it includes worldly knowledge as well. Some chapters of the noble Qur'an encourage studying the universe such as the chapters of $a l-R a^{\prime} d$ (The Thunder), al-Dukhan (The Smoke), al-Najm (The Star), al-Qamar (The Moon), al-Takweer (The Overthrowing), al-Infitar (The Cleaving), alInshiqaq (The Splitting Asunder), al-Buruj (The Big Stars), al-Tariq (The Night-Comer), al-Fajr (The Dawn), al-Balad (The City), al-Shams (The Sun), al-Layl (The Night), al-Dhuha (The Forenoon), al-'Asr (The Time) and al-Falaq (The Daybreak). Knowledge in the noble Qur'an is not limited to these titles. However, these topics are crucial for the Islamic television channel to produce content.

The second theme is wisdom. According to al-Seini (1986), Islam should be taught with wisdom and kindness. Being the main constitution of Muslims, the noble Qur'an is the book of wisdom. Allah (SWT) described it as \{Ya, Seen. By the wise Qur'an\} (al-Qur'an, 36: 1-2). The noble Qur'an also repeatedly makes different statements that refer to wisdom to draw the attention to its importance such as \{those of understanding\} (al-Qur'an, 3: 190), \{that you may use reason\} (al-Qur'an, 6: 151), \{that you might give thought (al-Qur'an, 2: 219) and \{those of intelligence\} (al-Qur'an, 20: 128). Besides, Allah (SWT) repeatedly stated that teaching wisdom is the main mission of Prophet Muhammad (PBUH) as clarified in (al-Qur'an, 2: 129), (al-Qur'an, 2: 151), (al-Qur'an, 3: 164) and (al-Qur'an, 62: 2),

The third theme is the Day of Judgment. It is a fundamental theme in the noble Qur'an. Almost half of the Qur'an is about the hereafter. The Prophet PBUH said:

$$
\text { "إِذَا زُلْزَلَتْ تَعْدِلن نِصْفَ الْقُرَآنِهِ. }
$$

The hadith means: "Idha Zulzilat is equal to half of the Qur'an" (Hadith, alTirmithi, Bab Ma Jaja' Fi Itha Zulzilat: 5: \#2894).

According to the late Grand Mufti of Syria, Kuftaro (1995), the chapter of Idha Zulzilat is equal to half of the Qur'an because almost half of the Qur'an accounts for the hereafter. Several chapters in the noble Qur'an remind us of the hereafter and its reward and punishment such as al-Zumar (The Groups), al-Jathiyah (Crouching), al-Waqi'ah (The Event), al-Hashr (The Gathering), al-Taghabun (Mutual Loss and Gain), al-Haqqah (The Inevitable), alMa'arij (The Ways of Ascent), al-Qiyamah (The Resurrection), al-Naba (The Great News), alGhashiyah (The Overwhelming), al-Zalzalah (The Earthquake) and al-Qari'ah (The Striking Hour). Similarly, the content of Islamic television should pay special attention to the hereafter.

The fourth theme is the history of Prophets and ancient nations. History in the noble Qur'an is usually stated in form of stories to attract attention. In an interview with Kanakir (2020) who is a researcher in Islamic communication, he emphasized the importance of 
stories in the noble Qur'an by saying that these stories can be transferred into all forms of drama such as films and series to attract the audience. Among other Prophets, incidents of Prophet Muhammad's life PBUH was reported in the noble Qur'an. The purpose of this narration is to study his biography and follow his guidance, teachings and instructions. For example, al-Isra (The Night Journey), Ta-Ha, al-Ahzab (The Combined Forces), Ya Seen, Muhammad, al-Fath (The Victory) and al-Muddaththir (The One Enveloped) are Qur'anic chapters that elaborate on Prophet Muhammad's life. Other chapters of the noble Qur'an relate the stories of other Prophets such as Ali-Imran (The Family of Imran), Yunus (Jonah), Hud (Hud), Yusuf (Joseph), Ibraheem (Abraham), al-Anbiya (The Prophets), al-Qasas (The Stories), Luqman, al-Ahqaf (The Curved Sand-hills) and Nuh (Kanakir, 2009). The abundance of these stories in the noble Qur'an is to attract our attention to their importance and consequently communicate them with audiences.

The fifth theme is the woman. Islam pioneered groundbreaking teaching to guarantee the rights of women, but unfortunately, the image of women in Islam is misrepresented. Islam is the religion that liberated women from slavery and consolidated their rights firmly. There are chapters in the noble Qur'an that are directly related to women such as al-Nisa's (The Women), al-Nur (The Light), al-Mujadilah (She That Disputed), al-Mumtahinah (The Woman to be examined), al-Talaq (The Divorce) and al-Tahreem (The Prohibition) (Kanakir, 2009). Currently, there is a dire need to manifest the position of women in Islam for both Muslims and non-Muslims because it is not well-known to even many Muslims.

The sixth theme is flora and fauna. Islam does not ask us to commit ourselves to worship and ignore worldly life. Even Allah SWT asked us in the noble Qur'an to supplicate Him to grant us a good life in this world and the next. The noble Qur'an is plentiful of the themes that are related to flora and fauna that form the essence of this life. For example, alBaqarah (The Cow), al-An'am (The Cattle), al-Nahl (The Bees) and al-Fil (The Elephant) are chapters that draw attention to the importance of fauna. The Fig chapter and many other verses draw attention to the importance of flora. Saba' (Sheba) chapter directs Muslims to organize and take care of farms. Other chapters serve as evidence of the importance of insects and making use of them like al-Naml (The Ants), al-Ankabut (The Spider) and al-'Alaq (The Clot).

The final theme is iron. Iron is the main material that contributed to the existence of modern civilization. The noble Qur'an contains a chapter titled al-Hadeed (The Iron). Allah (SWT) stated in the Noble Qur'an that AAnd We have sent down iron, wherein is a great strength and uses for mankind\} (al-Qur'an, 57: 25). Iron is not only meant for producing media technology but a weapon as well. The noble Qur'an encourages Muslims to produce weapons which are described as the weapons of defence not the attack as an indication that Islam is not an offensive religion. The weapon industry could not have taken place without iron. Chapter Saba (Sheba) draws attention to dam building, and it contains a call for the iron industry as well (Kanakir, 2009). Allah SWT stated in the noble Qur'an that Moreover, undoubtedly, We gave Daud a great grace from Us. O mountains! Turn towards Allah with him and $O$ birds! And We made the iron soft for him. That make wide coats of mail and keep regard of the measurement in the making, and you all do righteousness, Undoubtedly, I am seeing your works\} (al-Qur'an, 34: 10-11). 
This survey demonstrates that Islam is not limited to rites and worships, but it also contains issues about science, wisdom, morals and faith. It is also concerned with trade, agriculture, industry and handicrafts such as smithery, carpentry and building. Besides that, the noble Qur'an provides issues related to governments, authorities, economy, regulation, civilization and development. Kanakir (2009) states that two-thirds of the noble Qur'an teaches people the right way for establishing positive life which contributes to prosperity in nations and people. These themes form an abundant source for Islamic television content that can be produced in different formats such as cartoon, documentary, talks, drama, entertainment or news.

\section{AGENDA SETTING THEORY}

This study is based on Agenda-Setting theory. Ali et al. (2016) stated that the proponents of Agenda Setting theory are Maxwell McCombs and Donald Shaw in 1972. The original AgendaSetting theory examined elections. However, Agenda-Setting theory has been safely applied to a variety of communication situations far beyond the original academic domain (McCombs, 2005; Young \& McCarthy, 2009). Agenda Setting is one of the theories in mass communication that has been widely utilized by scholars (Idid, 2017). A study conducted by Bryant and Miron (2004) analyzed the articles of three leading journals from 1955 to 1999 found that Agenda Setting, among other five theories, were referenced more than 30 times. Agenda-Setting posits that the frequency of media coverage that issues receive can influence the public's perceptions regarding how important these issues are (Wanta \& Alkazemi, 2017). Wanta (2008) went further to clarify the impact of media by stating that the media may not be successful at influencing what the public thinks but is stunningly successful in influencing what the public thinks about. The repetition of messages about issues in the media day after day, along with the pervasiveness of the mass media in our daily lives, constitute a major source of media's influence on the audience (Mccombs, 2007). Mccombs (2007) also stated that the agenda-setting role of the media is not limited to focusing public attention on a particular set of issues, but also influences our understanding and perspective on the topics in the media.

\section{METHODOLOGY}

This paper is a content analysis study that implements the quantitative method. It aims at obtaining quantitative results from the content of the Alhijrah TV channel. The unit of analysis is the programs broadcast on the screen. Alhijrah was chosen because it is introduced as offering a variety of programs and at the same time adheres to the Islamic teachings in the content they broadcast. The sample of the study is the content of October, November and December of 2020 which make up the last season of the year. A full season was chosen to represent a full broadcasting plan. Alhijrah divides the year into 4 quarters each of which is considered a complete unit Firdaus (2021). Having observed the full season, it was noticed that all the weeks of a month have the same broadcasting schedule. That means every Monday, Tuesday, Wednesday, Thursday, Friday, Saturday and Sunday that fall in the same month broadcast the same programs but new episodes. This similarity reduced the need for the sample from the whole month to a single week from the month. Therefore, the sample was the first week of October, the second of November and the third of December.

Three methods were implemented: content analysis, observation and interview. The content analysis is implemented to analyze the content. The observation was implemented to observe the programs of Alhijrah as well as the whole production process. The researcher was attached for three months on daily basis to Alhijrah TV and had an opportunity to closely 
be in touch with those involved in the production of the content. The interview was conducted to clarify certain issues pertaining to the content.

A coding sheet was created benefitting from previous content analysis studies such as Al-Baghdadi (2010), Adwan (2012), Ma'iuf (2014), Kanaker and Zulkiple (2016), Kanaker, Rosidayu, Suria and Salah (2017), and also by Kanaker, Abughazlih and Kasmani (2020). The objective of this study is to discover the prioritized Islamic content broadcast by Alhijrah TV that contribute to shaping the perception of Islam among viewers. To achieve this objective, the frequency, percentage of the content were measured. Intercoder reliability was also implemented to ensure the accuracy of the data. Three coders run the coding independently. The agreement of the first round was $86 \%$, but after two more rounds, the coders were able to come to a complete match of the coding.

\section{RESULTS AND DISCUSSION}

Based on the observation, Alhijrah TV broadcasts 24 hours a day and 7 days a week. Having observed the content of the three-month season, it was found out that both October and November from midnight until 4 p.m. have the same schedule every day. December was similar except that the similar daily programs started from 2 a.m. instead of midnight. The variety of programs starts from 4 p.m. until midnight. In an interview with the digital media manager of Alhijrah TV (Fairos, 2020), he said that from midnight until 4 in the afternoon most viewers are either sleeping or at work. Most viewers start to go home at 4 o'clock and that is the right time to start a variety of programs.

According to Firdaus (2021), most of the Alhijrah programs are either 30 or 60 minutes long. The analysis of the sample of Alhijrah content shows that Alhijrah content is divided into 8 genres. The leading genre is a magazine. It accounts for $46.56 \%$ of the Alhijrah content. Shopping came right aftethe $r$ magazine. According to the previous CEO of Alhijrah TV Dato Azlan (2017), Alhijrah resorted to shopping becaua se of a lack of financial capital and shopping is the available means of income for them. The statement of the previous CEO is corroborated by the current new media manager (Fairos, 2020) who stated the same reason for having this large frequency of shopping programs. Shopping was followed by capsules/ filler then live programs which is followed by a few animation, drama, concert and live talk show as shown in Table 1.

Table 1: Genres of Alhijrah TV Content

\begin{tabular}{lccc}
\hline No. & Genre & Frequency & Percentage \\
\hline 1 & Magazine & 349 & $46.56 \%$ \\
2 & Shopping & 131 & $17.10 \%$ \\
3 & Capsules /fillers & 129 & $16.84 \%$ \\
4 & Live & 128 & $16.71 \%$ \\
5 & Animation & 11 & $1.43 \%$ \\
6 & Drama & 10 & $1.30 \%$ \\
7 & Concert & 5 & $0.65 \%$ \\
8 & Live Talk Show & 3 & $0.39 \%$ \\
& Total & $\mathbf{7 6 6}$ & $\mathbf{1 0 0 \%}$ \\
\hline
\end{tabular}

The magazine genre was composed of 36 programs ranging from a frequency of 84 to only once. My Qur'an Time was not only the most frequent magazine program but also the most frequent among all other genres. It is an hour of recitation and explanation of the noble Qur'an that is repeated 4 times a day. It was hosted by two ustazs. The first ustaz recites the 
verses and the other explains. The audience can contact the program through Facebook. It accounts for 4 hours out of 24 daily. The second magazine program was also a recitation of the noble Qur'an. It is daily ten-minute programs that are aired at 5:15 in the morning. The third program was also an hour recitation of the Qur'an that was aired daily at 1 a.m. except for Saturday and Sunday of December because it was replaced by a four-hours Qur'an program titled Maraton Qurantime.

The Qur'an programs that are dominating the screen are followed by Cinta IImu. It was half an hour program that is broadcast daily at 6 p.m. except Sundays. It accounted for $7.75 \%$ of magazine programs as shown in table 2 below. All the 15 programs of the frequency of 3 shown in Table 2 are weekly programs that are broadcast once a week. These programs are broadcast in the peak hours of Alhijrah which are 4 pm until midnight. They are a combination of programs that focus on a variety of topics such as life in the grave, figh, tasawuf, hadith, aqidah, fatwa, life after death, cooking and women. All the programs that were broadcast once, shown at the end of Table 2, were aired in October except Tawajjuh which was in December. These programs did not follow the seasonal division of the programs. According to Firdaus (2021), some of the programs are extended to more than a period of a single season whereas others are not long enough to cover the whole season.

Table 2: Magazine Programs of Alhijrah TV

\begin{tabular}{|c|c|c|c|c|}
\hline No. & Name of the program & Genre & Frequency & Percentage \\
\hline 1 & My Qur'an Time & Magazine & 84 & $34.28 \%$ \\
\hline 2 & Surah Alquran & Magazine & 21 & $8.57 \%$ \\
\hline 3 & Alunan Bacaan Al-Qur'an Sheik Musyairi & Magazine & 19 & $7.75 \%$ \\
\hline 4 & Cinta IImu & Magazine & 19 & $7.75 \%$ \\
\hline 5 & Saat Syahdu & Magazine & 14 & $5.71 \%$ \\
\hline 6 & E-Kaunter Netizen SS3 (RPT) & Magazine & 8 & $3.26 \%$ \\
\hline 7 & Ku Seru Nama Mu & Magazine & 6 & $2.44 \%$ \\
\hline 8 & Sentuhan Kalbu & Magazine & 5 & $2.04 \%$ \\
\hline 9 & Menu Alam & Magazine & 4 & $1.63 \%$ \\
\hline 10 & Surah Yassin & Magazine & 4 & $1.63 \%$ \\
\hline 11 & Alqariah & Magazine & 3 & $1.22 \%$ \\
\hline 12 & Wanita & Magazine & 3 & $1.22 \%$ \\
\hline 13 & Global Arab & Magazine & 3 & $1.22 \%$ \\
\hline 14 & Fiqh Syariah & Magazine & 3 & $1.22 \%$ \\
\hline 15 & The Truth & Magazine & 3 & $1.22 \%$ \\
\hline 16 & Kasih Kenyalang & Magazine & 3 & $1.22 \%$ \\
\hline 17 & Tasawuf Harian & Magazine & 3 & $1.22 \%$ \\
\hline 18 & Celik Hadis & Magazine & 3 & $1.22 \%$ \\
\hline 19 & Ayat Riwayat & Magazine & 3 & $1.22 \%$ \\
\hline 20 & Akidah \& Falsafah & Magazine & 3 & $1.22 \%$ \\
\hline 21 & Alam Barzakh & Magazine & 3 & $1.22 \%$ \\
\hline 22 & Mimber & Magazine & 3 & $1.22 \%$ \\
\hline 23 & Medan Fatwa & Magazine & 3 & $1.22 \%$ \\
\hline 24 & Almulk & Magazine & 3 & $1.22 \%$ \\
\hline 25 & Mentari Palestin & Magazine & 3 & $1.22 \%$ \\
\hline 26 & Tijarah & Magazine & 2 & $0.81 \%$ \\
\hline 27 & Coffee with Mufti & Magazine & 2 & $0.81 \%$ \\
\hline 28 & Haflah Al Quran & Magazine & 2 & $0.81 \%$ \\
\hline 29 & 30 Minit Ustaz Don Daniyal & Magazine & 2 & $0.81 \%$ \\
\hline 30 & Maraton Qurantime (RPT) & Magazine & 2 & $0.81 \%$ \\
\hline 31 & Duo Syamsul & Magazine & 1 & $0.40 \%$ \\
\hline 32 & Chef Ammar & Magazine & 1 & $0.40 \%$ \\
\hline 33 & Fajar Iman Di Bumi Nihon & Magazine & 1 & $0.40 \%$ \\
\hline
\end{tabular}




\begin{tabular}{ccccc}
\hline 34 & Alhramain & Magazine & 1 & $0.40 \%$ \\
35 & Minit Duke (RPT) & Magazine & 1 & $0.40 \%$ \\
36 & Tawajjuh & Magazine & 1 & $0.40 \%$ \\
& Total & & $\mathbf{2 4 5}$ & $\mathbf{1 0 0 \%}$ \\
\hline
\end{tabular}

As mentioned above, shopping programs were the second most frequent content of Alhijrah. Alhijrah had five shopping programs. The most frequent is Sarang Media $(45.80 \%)$ which is a direct selling program from a Korean company (Firdaus, 2021). Go Shop, Jom Shoppe and Go Shop X Alhijrah are daily programs that last for an hour each. Go Shop is aired every day at 10 o'clock in the morning followed by Jom Shoppe, while Go Shop X Alhijrah is aired at $2 \mathrm{pm}$. Go Shop is a direct selling program from Alhijrah TV and ASTRO which stands for All-Asian Satellite Television and Radio Operator. Go Shop X Alhijrah is hosted by a host from Alhijrah itself. Bazaar Jom is also another shopping program where a host for Alhijrah together with a guest promote certain products. This program was the least frequent as shown in Table 3. Based on observation, Alhijrah promotes only halal products such as cleaning products, cookware, food and even educational institutions.

Table 3: Shopping Programs of Alhijrah TV

\begin{tabular}{lcccc}
\hline No. & Name of the program & Genre & Frequency & Percentage \\
\hline 1 & Sarang Media & Shopping & 60 & $45.80 \%$ \\
2 & Go Shop & Shopping & 21 & $16.03 \%$ \\
3 & Jom Shoppe & Shopping & 21 & $16.03 \%$ \\
4 & Go Shop X Alhijrah & Shopping & 21 & $16.03 \%$ \\
5 & Bazaar Jom & Shopping & 8 & $6.10 \%$ \\
& Total & & $\mathbf{1 3 1}$ & $\mathbf{1 0 0 \%}$ \\
\hline
\end{tabular}

The third frequent genre of the Alhijrah content is capsules or they are also called fillers. It is noteworthy to mention that this genre is frequent, but it does not account for a long time on the screen because they are short. They are used to fill the time between programs. Most of the capsules last for 5 minutes. However, Seminit Je is a two-minute capsule aired once daily. Alhijrah has a combination of capsules that lasts for half an hour. It is aired five times a day. One of these capsules is the five-time Azan (call for prayer). The Malaysia prayer times throughout the year change almost half an hour. Therefore, the azan might come at the beginning, middle or end of this combination. Therefore, this combination of capsules is broadcast daily except for Thursday of December because it is replaced with a live news bulletin as shown in Table 4 below. The less frequent capsules offer a variety of content such as husband-wife relationship, advice, supplication and recipes.

Table 4: Capsules/ Fillers Programs of Alhijrah TV

\begin{tabular}{|c|c|c|c|c|}
\hline No. & Name of the program & Genre & Frequency & Percentage \\
\hline 1 & Seminit Je & Capsules/ fillers & 21 & $9.01 \%$ \\
\hline 2 & Doa-Doa & Capsules/ fillers & 21 & $9.01 \%$ \\
\hline 3 & Selawat-Selawat & Capsules/ fillers & 21 & $9.01 \%$ \\
\hline 4 & Zikir-Zikir & Capsules/ fillers & 21 & $9.01 \%$ \\
\hline 5 & $\begin{array}{l}\text { Kapsul Selawat/ Panggilan Agung/ } \\
\text { Azan Subuh }\end{array}$ & Capsules/ fillers & 21 & $9.01 \%$ \\
\hline 6 & Panggilang Agung/ Azan Zohor & Capsules/ fillers & 21 & $9.01 \%$ \\
\hline 7 & Panggilang Agung/ Azan Asr & Capsules/ fillers & 21 & $9.01 \%$ \\
\hline 8 & $\begin{array}{l}\text { Kapsul Salawat/ Panggilan Agung/ } \\
\text { Azan Maghrib }\end{array}$ & Capsules/ fillers & 21 & $9.01 \%$ \\
\hline
\end{tabular}




\begin{tabular}{lcccc}
\hline 9 & Panggilan Agung Isyak & Capsules/ fillers & 20 & $8.58 \%$ \\
10 & CSI: Cinta Suami Isteri & Capsules/ fillers & 10 & $4.29 \%$ \\
11 & Nasa'ih Jiwa & Capsules/ fillers & 10 & $4.29 \%$ \\
12 & Teladan \& Sempedan & Capsules/ fillers & 10 & $4.29 \%$ \\
13 & Inilah Doaku & Capsules/ fillers & 5 & $2.14 \%$ \\
14 & Cendekiawan Islam & Capsules/ fillers & 3 & $1.28 \%$ \\
15 & Kisah Sahabat & Capsules/ fillers & 3 & $1.28 \%$ \\
16 & Bayan Linnas & Capsules/ fillers & 2 & $0.85 \%$ \\
17 & Resepi Juadah Anda & Capsules/fillers & 2 & $0.85 \%$ \\
& Total & & $\mathbf{2 3 3}$ & $\mathbf{1 0 0 \%}$ \\
\hline
\end{tabular}

Alhijrah has seven live programs that made up $16.71 \%$ of the content. The most frequent live program is the news bulletin. Alhijrah offers local news on daily basis except on Sunday international news is broadcast. Alhijrah tries to handle its news from an Islamic point of view by hosting religious figures to comment on the news such as muftis or academicians from Islamic fields. In both October and November the news bulletins were broadcast at $8 \mathrm{pm}$ and repeated at midnight. However, in December there was no repetition because the schedule was filled with concerts.

Assalamualaikum Ustaz is a daily morning program aired at seven o'clock and repeated on Sunday at 7:30 pm and Wednesday at 11:30 pm. The ustaz who is the host of the program gives a talk for half an hour, but he communicates with the audience through Facebook. He reads the questions and answers them, while the Facebook page appears on the screen. Assalamualaikum \& Assalam Biz is also a morning daily program that lasts for 2 hours. A variety of topics are discussed. Every day new guests from different sectors attend to promote their ideas, institutions and even their products. It is an in-house program that Alhijrah broadcast from their studio.

Malam Dhijrah Tab Mekah is a daily three-hour program that is aired live on Mecca TV. It shows scenes of the Ka'bah and Alharam Mosque associated with Qur'an recitation. This program starts at 2 a.m. and ends at five. Global Hijrah is a fifteen-minute analysis of current issue (Firdaus, 2021). This program accounts for almost $14 \%$ of the live programs. Analysis and Solat Jumaat are two weekly programs. The analysis is a studio talk of current affairs with a specialist in that affair. Solat Jumaat is a live broadcast of Friday Prayer every Friday as shown in Table 5.

Table 5: Live Programs of Alhijrah TV

\begin{tabular}{lcccc}
\hline No. & Name of the program & Genre & Frequency & Percentage \\
\hline 1 & Berita Al-Hijrah & Live & 35 & $27.34 \%$ \\
2 & Assalamualaikum Ustaz & Live & 27 & $21.09 \%$ \\
3 & Assalamualaikum \& Assalam Biz & Live & 21 & $16.40 \%$ \\
4 & Malam Dhijrah Tab Mekah & Live & 21 & $16.40 \%$ \\
5 & Global Hijrah & Live & 18 & $14.06 \%$ \\
6 & Analisis & Live & 3 & $2.34 \%$ \\
7 & Solat Jumaat & Live & 3 & $2.34 \%$ \\
& Total & & $\mathbf{1 2 8}$ & $100 \%$ \\
\hline
\end{tabular}

Besides the above-mentioned major genres, Alhijrah broadcast animation, drama, concert and live talk show content. However, these programs are not as frequent. The total frequency of animation programs was 11 as shown in Table 6 . Anifest is an animation program that lasts for 5 minutes. Jom Dengar Cerita is also 5 minutes where a teacher narrates a story 
for kids in the kindergarten associated with some of the drawings and for that reason, it is considered semi-animation.

Table 6: Minor Genres of Alhijrah Content

\begin{tabular}{lcccc}
\hline No. & Name of the program & Genre & Frequency & Total \\
\hline 1 & Anifest & Animation & 6 & \multirow{2}{*}{11} \\
2 & Jom Dengar Cerita & Semi-Animation & 5 & \\
3 & Boss Mama Kirim Salam & Drama & 4 & \multirow{2}{*}{10} \\
4 & Bioskop Hijrah & Drama & 4 & \\
5 & Telemovie & Drama & 2 & \\
6 & Diskonsert Iman \& Aman & Concert & 1 & \\
7 & Konsert Akustika Hijrah & Concert & 1 & 5 \\
8 & Konsert The Journey of Nur & Concert & 1 & \\
9 & Hijrah Bersalawat & Concert & 1 & \\
10 & Konsert Rahmah & Concert & 1 & 3 \\
11 & 60 Min Bersama & Live Talk Show & 3 & \\
\hline
\end{tabular}

Moreover, Alhijrah broadcast three drama programs as shown in table 6 . The most famous drama of Alhijrah is Boss Mama Kirim Salam. Alhijrah advertised this program on their website by stating that for the first time in the history of the broadcasting world or at least the history of Alhijrah TV, a production of in-house dramas is aired to meet the audience in Malaysia. This drama was recorded inside the studio of Alhijrah.

Finally, Alhijrah broadcast five concerts only in December. They have aired from 11 pm until 1 is. Alhijrah also aired a single weekly live talk show program, 60 Min Bersama, every Tuesday at $9 \mathrm{pm}$. Alhijrah hosts people from different organizations such as waqaf (endowment) institute to discuss their current situation and what they are offering for the people.

\section{CONCLUSION}

The content analysis of this study showed that the major agenda of the Alhijrah TV is the noble Qur'an. My Qur'an Time occupies four hours daily. Malam Dhijrah Tab Mekah is also a three-hour daily program of Qur'an recitation with live scenes of Alharam Mosque in Mecca. Alunan Bacaan Al-Qur'an Sheik Musyairi is also a daily Qur'an program that lasts for an hour. Surah Al-Quran and surah Yassin are also Qur'an programs. Some of these programs like My Qur'an Time go beyond recitation to explain the meaning of the recited verses. However, focusing on the implementation of the Qur'an which is a book that is valid to guide human beings to live a better life and deep explanation of the noble Qur'an and relating it to our daily life was not a dominant feature of these programs.

The analysis also showed that almost 16 hours of Alhijrah every day, starting from midnight until 4 p.m., are the same programs. The variety of programs was only eight out of twenty-four hours. According to Fairos (2020), Alhijrah is struggling in terms of financial capital and to broadcast a variety of programs around the clock costs an incredible amount of money which Alhijrah does not afford. It is the same reason attributed to the rarity of drama and cartoon programs and made Alhijrah resort to more studio-programs.

Shopping was the second most frequent genre of programs. Alhijrah devoted five programs for shopping to sustain their income to keep the channel running. Alhijrah restricted their shopping programs to halal products only. On the contrary, life after death was very limited even though it is a major theme of the noble Qur'an. Therefore, it is advised that 
Alhijrah TV prioritize the issues that the Allah SWT prioritized in His book during setting the agenda of Islamic content. As Muslims, we have to prioritize what Allah made a priority because that is the best guidance that contributes to the improvement of our life in this world and the future.

It is expected that this study assists the producers of Islamic content whether TV stations, production houses or even individuals who are sharing the Islamic message in not only television but social media to focus on the most needed content. This study also contributes to the theoretical development by discovering the centre agenda of the Islamic content offered to the audience by Alhijrah TV which is the noble Qur'an.

\section{BIODATA}

Osama Kanaker is a senior lecturer at the Communication Program, Faculty of Leadership and Management, Islamic Science University of Malaysia. He is an advisor of Jurnal Komunikasi Profitik. He was an editor and evaluator of Al-Abqari journal for five years. He has published several books and articles on Islam and communication. He has a Communication and Islamic background. The field of interest is communication and Islam. Email: osama@usim.edu.my. 


\section{REFERENCES}

Adwan, A. H. (2012). Taghtiyat assahafa al-Isra'iliyah lilharb ala Ghaza 2008-2009: Dirasah tahliliyah wasfiyah muqaranah lithalath suhuf Isra'iliah [Master Research, Al-Azhar University, Gaza].

Al Seini, S. (1986). An Islamic concept of news. American Journal of Islamic Social Sciences, 3(2), 277.

Alhijrah TV. (2021). Alhijrah Official Website. https://www.tvalhijrah.com/

Al-Qudat, M. F. (1994). Al-Tilfizyon wa al-Film. Amman: Dar al-Fikr.

Al-Termithi, M. I. (n.d.) Sunan al-Termithi [Ahmad Muhammad Shakir, ed.]. Cairo: Dar alHadith.

Ayish, M. I. (2002, Nov 1). The impact of Arab satellite television on culture and value systems in Arab countries: Perspectives and issues. Arab Media and Society Journal. https://www.arabmediasociety.com/the-impact-of-arab-satellite-

Boyd, D. A. (1982). Broadcasting in the Arab world: A study of radio and television in the Middle East. Philadelphia: Temple University Press.

Bryant, J., \& Miron, D. (2004). Theory and research in mass communication. Journal of Communication, 54(4), 662-704.

Buyong, M., \& Ismail, R. (2010). Islamic programs in Malaysian free-to-air television channels. Department of Communication, International Islamic University Malaysia, 125. https://core.ac.uk/download/pdf/300384757.pdf

Davies, Merryl Wyn. (1987). Serving the public: Muslim presence on the airwaves". In Anon., Beyond frontiers: Islam and contemporary needs. Mansell.

Mohd Fairos Ibrahim. (2020). Alhijrah media corporation [An interview].

Idid, S. A. (2017). Agenda setting: Probing the issues during the 13th general election. Jurnal Komunikasi: Malaysian Journal of Communication, 33(2).

Kanaker, O., Abughazlih, M. O., \& Kasmani, M. F. (2020). Media framing of minorities' crisis: A study on Aljazeera and BBC News coverage of the Rohingya. Jurnal Komunikasi: Malaysian Journal of Communication, 36(2).

Kanaker, O., Sabran, R., Rahman, S. H., \& Ibrahim, S. M. Z. (2017). The authenticity of characters portrayal in Islamic films: A study on the message. Al-'abqari Journal, 12(Special Edition), 47-57.

Kanaker, O., \& Zulkiple A. Ghani. (2016). Programs analysis of Islamic-based television the experience of al-Hijrah Malaysian television. Advances in Natural and Applied Sciences Journal, 10(2), 36-45.

Kanakir, M. (2009, Jan 6). Maudu'at al-d'wah wa al-i'lam fi al-waqt al-mu'asir [Paper organized by USIM].

Kanakir, M. (2020). Islamic content of media [An interview].

Kanakir, M. (2007). Al-I'lam al-Islami abr al-qanawat al-fadaiah Dirasah Tatbiqiah ala alqanawat al-fadaiah al-Arabiah Iqra wa al-Majd wa al-Manar [PhD. Thesis, Islamic Science University of Malaysia].

Kuftaro, A. (1985). Tafseer surat Alzalzalah. Kuftaro Institute.

Ma'iuf, A. M. (2014). Ma'aiyyr attaghtiya al-ikhbariah fi al-qanawat atilfizyuniah. Al-Balqa Journal for Research and Studies, 17(1), 165-189.

McCombs, M. (2005). A look at agenda-setting: Past, present and future. Journalism Studies, 6(4), 543-557. 
McCombs, M., \& Valenzuela, S. (2007). The agenda-setting theory. Cuadernos de información, 20, 44-50.

Mohd Firdaus Ab. Samad. (2021). Alhijrah media corporation [An interview].

Moll, Y. (2010). Islamic televangelism: Religion, media and visuality in contemporary Egypt". Arab Media and Society, 1-27.

Pasha, S. H. (1993). Towards a cultural theory of political ideology and mass media in the Muslim world. Media, Culture and Society, 15, 61-79.

Rosidayu Sabran. (2010). Factors influencing religious programmes in the changing landscape of Malaysia's private television broadcasting. In M. Buyong, N. K. A. Karim, S. H. Yusoff, S. H. Rahman (Eds.). Faculty of Leadership and Management USIM.

Rugh, W. A. (2007). Do national political systems still influence Arab Media?. Arab Media and Society. https://www.arabmediasociety.com/do-national-political-systems

Saheeh International. (1997). Translation of the meaning of the Qur'an.

Salman, A., Mustaffa, N., Salleh, M. A. M., \& Ali, M. N. S. (2016). Social media and agendasetting: Implications on political agenda. Jurnal Komunikasi: Malaysian Journal of Communication, 32(1).

Wanta, W. (2008). Applying agenda-setting research in an international context: A roadmap for future research. Ecos de la Comunicación, 1(1). https://core.ac.uk/download/pdf/

Wanta, W., \& Alkazemi, M. F. (2017). Agenda-setting: History and research tradition. The International Encyclopedia of Media Effects, 1-14.

Wilt, B. A. (n.d.). Television history: The beginning of a new medium. http://tvhistory.tripod.com/paper.html

Young, R., \& McCarthy, K. (2009). Why do municipal issues arise on the federal policy agenda in Canada? Canadian Public Administration, 52(3), 347-370.

Zulkiple Abd. Ghani. (1998). Diffusion of Islamic message through television: The experience of television Malaysia. UKM.

Zulkiple Abd. Ghani. (2006). Islamic broadcasting a search for Islamic identity. Hamdard Islamicus, XXIX(April- June), 29. 